\title{
Angiomatoid fibrous histiocytoma: unusual sites and unusual morphology
}

\author{
Gang Chen ${ }^{1}$, Andrew L Folpe ${ }^{2}$, Thomas V Colby ${ }^{3}$, Kesavan Sittampalam ${ }^{4}$, Martine Patey ${ }^{5}$, \\ Ming-Guang Chen ${ }^{6}$ and John KC Chan $^{7}$ \\ ${ }^{1}$ Department of Pathology, Fujian Provincial Tumor Hospital, Fuzhou, Fujian, China; ${ }^{2}$ Department of \\ Pathology, Mayo Clinic, Rochester, MN, USA; ${ }^{3}$ Department of Pathology, Mayo Clinic, Scottsdale, AZ, USA; \\ ${ }^{4}$ Department of Pathology, Singapore General Hospital, Singapore; ${ }^{5}$ Department of Pathology, Hopital Robert \\ Debre-CHU, Cedex, France; ${ }^{6}$ Department of Pathology, The First Affiliated Hospital in Nanping of Fujian \\ Medical University, Nanping, Fujian, China and ${ }^{7}$ Department of Pathology, Queen Elizabeth Hospital,
} Kowloon, Hong Kong

\begin{abstract}
Angiomatoid fibrous histiocytoma is a soft tissue neoplasm of low malignant potential, typically occurring in the superficial soft tissues of the extremities in children and young adults. Occurrence outside somatic soft tissues is most uncommon. This report describes eight such cases, involving the lung (three cases), mediastinum (one case), vulva (two cases), retroperitoneum (one case) and ovary (one case), with the latter three locations being hitherto unreported sites of occurrence. Patients had a median age of 48 years, and presented with symptoms related to the mass lesion (five cases) or were incidentally found to harbor a tumor (three cases). Besides the typical histological features such as an outer shell of lymphoid tissue, multinodular aggregates of dendritic-like tumor cells, blood-filled spaces and abundant admixed plasma cells, unusual features were found focally in some cases, including clear cells, rhabdomyoblast-like cells, pulmonary edemalike pattern and tumor cell cords lying in a myxoid stroma. Immunoreactivity for the epithelial membrane antigen, desmin, smooth-muscle actin, CD68 and CD99 was found in 100, 63, 43, 100 and 100\% of cases, respectively. Molecular studies provided support for the diagnosis in all seven tested cases-EWS gene translocation in six cases (partner gene being CREB1 in three and ATF1 in two in which information was available) and FUS gene translocation in one case. Comparison of the reported cases of extrasomatic angiomatoid fibrous histiocytoma with their somatic soft tissue counterparts showed a number of differences: higher mean age, slight male predominance (particularly for bone lesions), larger tumors, higher frequency of systemic symptoms, higher recurrence rate, myxoid change being more common and a much higher frequency of EWS/ATF1 gene fusion.
\end{abstract}

Modern Pathology (2011) 24, 1560-1570; doi:10.1038/modpathol.2011.126; published online 5 August 2011

Keywords: angiomatoid fibrous histiocytoma; mediastinal neoplasm; ovarian neoplasm; retroperitoneal neoplasm; soft tissue tumor; vulval neoplasm

Angiomatoid fibrous histiocytoma is an uncommon, low-grade malignant soft tissue tumor of uncertain histogenesis. It most commonly occurs in the deep dermis or subcutis of the extremities in children and young adults. ${ }^{1-3}$ Only rarely does this tumor occur outside somatic soft tissues, with 12 cases having

Correspondence: Dr JKC Chan, Department of Pathology, Queen Elizabeth Hospital, Wylie Road, Kowloon, Hong Kong, SAR China.

E-mail: jkcchan@ha.org.hk

Received 11 April 2011; revised 15 June 2011; accepted 15 June 2011; published online 5 August 2011 been reported so far, including the brain, mediastinum, lung, bone and omentum. ${ }^{4-13}$ In this report, we describe the clinicopathological and molecular features of eight cases of extrasomatic angiomatoid fibrous histiocytoma, and analyze these cases together with the previously reported cases to determine whether there are differences from classical angiomatoid fibrous histiocytoma. It is noteworthy that this study reports for the first time the occurrence of angiomatoid fibrous histiocytoma as a primary tumor in the vulva, ovary and retroperitoneum, broadening the anatomical locations that can be affected by this tumor type. 


\section{Materials and Methods}

\section{Case Selection}

The eight cases were collected from the consultation files of four of the authors (GC, ALF, TVC and JKCC), and included one pulmonary case we have previously reported. ${ }^{8}$ Clinical data were obtained, and available histological sections were retrieved for review.

\section{Immunohistochemical Staining}

Immunohistochemical staining was performed using the BOND-MAX automated immunostainer (Vision Biosystems, Leica), with a polymer-based detection system. The antibodies are shown in Table 1 . The antigen-retrieval method was on-board heat-induced epitope retrieval at alkaline $\mathrm{pH}(\mathrm{pH} 9.0)$.

\section{Molecular Analysis}

Paraffin sections were available from seven cases for molecular analysis. Dual-colored fluorescence in situ hybridization (FISH) was performed using EWS break-apart probe and/or FUS break-apart probe (Vysis, Abbott Molecular, IL, USA), in which splitting of normally fused red and green signals (which sometimes appeared as a single yellow signal because of overlap of the signals) into separate red and green signals indicated the presence of EWS or FUS gene translocation. The slides were viewed under a Nikon fluorescent microscope using appropriate filters (Nikon, ECLIPSE E600).

Messenger RNA was extracted from sections of paraffin-embedded tumor tissues. Nested reverse transcription-PCR (RT-PCR) was carried out to detect $E W S / A T F 1$ and EWS/CREB1 fusion transcripts according to previously described methods. ${ }^{14-16}$ Appropriate positive and negative controls were included. PCR products were electrophoresed on a $2 \%$ agarose gel.

\section{Results}

\section{Clinical Features}

The eight patients included three men and five women, with age ranging from 22 to 65 years (median and mean: 48 years) (Table 2). The involved sites included the lung $(n=3)$, vulva $(n=2)$, retroperitoneum $(n=1)$, mediastinum $(n=1)$ and ovary $(n=1)$. Three patients were incidentally discovered to have a tumor, whereas five patients presented with symptoms referable to the anatomical location, such as mass lesion or hemoptysis. One of the latter patients (case 7) also had fever, increased serum C-reactive protein and systemic symptoms. All patients were treated by surgery, without adjuvant radiotherapy or chemotherapy. One patient (case 4) had local tumor recurrence 2 years after incomplete excision of the vulval mass, and remained well 4 years after re-excision. Six other patients with follow-up information had remained well, at followup time of 3 months to 2 years.

\section{Pathological Findings}

The tumors ranged in size from 1.5 to $6.0 \mathrm{~cm}$, with a mean of $3.0 \mathrm{~cm}$ and a median of $2.5 \mathrm{~cm}$. They were circumscribed, with grayish-yellow solid cut surfaces, sometimes interspersed with hemorrhagic foci.

Histologically, the tumors were surrounded by an incomplete fibrous pseudocapsule. The most

Table 1 Results of immunostaining and molecular studies

\begin{tabular}{|c|c|c|c|c|c|c|c|c|c|}
\hline \multirow[t]{2}{*}{ Test } & \multirow[t]{2}{*}{ Source } & \multicolumn{8}{|c|}{ Case number } \\
\hline & & 1 & 2 & 3 & 4 & 5 & 6 & 7 & 8 \\
\hline \multicolumn{10}{|l|}{ Immunostaining $\mathrm{a}$} \\
\hline Cytokeratin & MNF-116, Dako & - & - & - & - & + & + & - & - \\
\hline Epithelial membrane antigen (EMA) & GP1.4, Lab Vision & +++ & ++ & ++ & +++ & + & +++ & +++ & +++ \\
\hline Desmin & D33, Dako & + & + & - & + & - & +++ & - & ++ \\
\hline Smooth-muscle actin (SMA) & 1A4, Zymed/Invitrogen & - & + & - & +++ & NA & - & + & - \\
\hline CD68 & PGM1, Dako & ++ & ++ & ++ & +++ & ++ & ++ & ++ & + \\
\hline CD99 & O13, Signet & NA & + & NA & ++ & NA & ++ & +++ & +++ \\
\hline CD21 & NCL-CD21-2G9, Novocastra/Leica & - & - & - & - & - & - & + & - \\
\hline Ki67 & SP6, Lab Vision & NA & $3 \%$ & NA & $3 \%$ & NA & $4 \%$ & $3 \%$ & $2 \%$ \\
\hline \multicolumn{10}{|l|}{ Molecular studies } \\
\hline FISH for EWS & Break-apart probe, Vysis & + & + & NA & + & + & + & - & + \\
\hline FISH for FUS & Break-apart probe, Vysis & NA & NA & NA & NA & NA & NA & + & NA \\
\hline RT-PCR for EWS-CREB1 & In-house primers & - & + & NA & + & NA & + & NA & - \\
\hline RT-PCR for $E W S$-ATF1 & In-house primers & + & - & NA & - & NA & - & NA & + \\
\hline
\end{tabular}

$\mathrm{NA}=$ not available.

${ }^{\mathrm{a}}$ Quantification of immunostaining: $-=0 \%$ tumor cells positive; $+=1-25 \%$ tumor cells positive; $++=26-50 \%$ tumor cells positive; $+++=>50 \%$ tumor cells positive. 
Table 2 Summary of angiomatoid fibrous histiocytoma occurring outside somatic soft tissues (current series and cases reported in literature)

\begin{tabular}{|c|c|c|c|c|c|}
\hline Source & $\begin{array}{l}\text { Sex/age } \\
\text { (years) }\end{array}$ & $\begin{array}{l}\text { Tumor location } \\
\text { and maximum } \\
\text { dimension }\end{array}$ & Presentation & Outcome & $\begin{array}{l}\text { Molecular } \\
\text { genetics }\end{array}$ \\
\hline
\end{tabular}

\begin{tabular}{lll}
\hline $\begin{array}{l}\text { Current series, } \\
\text { Case } 1^{8}\end{array}$ & $\mathrm{M} / 46$ & $\begin{array}{l}\text { Lung (right lower } \\
\text { lobe), } 2.5 \mathrm{~cm}\end{array}$ \\
$\begin{array}{l}\text { Current series, } \\
\text { Case } 2\end{array}$ & $\mathrm{~F} / 60$ & $\begin{array}{l}\text { Lung (left upper } \\
1.5 \mathrm{~cm}\end{array}$ \\
$\begin{array}{l}\text { Current series, } \\
\text { Case } 3\end{array}$ & $\mathrm{M} / 43$ & Lung, $2.4 \mathrm{~cm}$ \\
$\begin{array}{l}\text { Current series, } \\
\text { Case } 4\end{array}$ & $\mathrm{~F} / 44$ & Vulva (left), $2 \mathrm{~cm}$ \\
& &
\end{tabular}

Current series, $\quad$ F/65 Vulva, $2.5 \mathrm{~cm}$

Case 5

Current series, $\quad \mathrm{F} / 2$

Case 6

Current series, $\quad F / 49$

Case 7

Current series,

Mediastinum

(anterior), $2 \mathrm{~cm}$

Davies et al

F/24

Mediastinum, $3.5 \mathrm{~cm}$

\begin{tabular}{|c|c|c|}
\hline Asakura et $a l^{5}$ & $\mathrm{M} / 39$ & $\begin{array}{l}\text { Mediastinum } \\
\text { (adjacent to the left } \\
\text { main pulmonary } \\
\text { artery and the } \\
\text { descending aorta), } \\
4.5 \mathrm{~cm}\end{array}$ \\
\hline $\begin{array}{l}\text { Tanas et } a l^{10} \text {, } \\
\text { Case } 4\end{array}$ & $\mathrm{~F} / 29$ & Omentum \\
\hline Dunham et $a l^{4}$ & $\mathrm{M} / 25$ & $\begin{array}{l}\text { Brain (left occipital), } \\
5.3 \mathrm{~cm}\end{array}$ \\
\hline Ochalski et $a l^{11}$ & $\mathrm{M} / 35$ & $\begin{array}{l}\text { Brain, } 0.5 \mathrm{~cm} \\
\text { (accompanied by a } \\
4-\mathrm{cm} \text { hematoma) }\end{array}$ \\
\hline
\end{tabular}

Retroperitoneum and liver), $5 \mathrm{~cm}$
Chest tightness for 1 month

Hemoptysis

Incidental discovery of coin lesion on chest X-ray

Had history of endometrial and ovarian carcinoma, treated by surgery in the year 2001. At that time, a mobile, slow-growing vulval mass $(1 \mathrm{~cm})$ was already observed. Vulval mass excised in 2004 with positive margins, and diagnosed as 'schwannoma'

Vulval mass, clinically believed to be Bartholin cyst. Biopsy performed

Incidental ultrasound finding of right ovarian mass, which was excised 2 years later (between right adrenal

Abdominal pain and systemic inflammatory symptoms. Retroperitoneal mass found on imaging studies

Had history of nasopharyngeal carcinoma, treated by radiotherapy in

1997. Follow-up surveillance CT scan in 2010 revealed a mediastinal mass

Fever, malaise, night sweat, and weight loss. MRI showed mediastinal mass adjacent to the right ventricle and pulmonary outflow tract

Incidental discovery of abnormality in chest X-ray on routine medical examination

NA

Visual disturbance and headache

Worsening headache, due to intracerebral hemorrhage from a tumor located in the left temporal lobe
NA

Excision. Well at 2 years

EWS/ATF1

Excision. Well at 17 months

NA

EWS/CREB1

NA

Local recurrence after 2 years in 2006, with a size of $2.8 \mathrm{~cm}$. Review diagnosis of original lesion was angiomatoid fibrous histiocytoma, and wide excision was performed. Well 6.5 years after first excision

Biopsy followed by wide re-excision. Well at 6 months

Well at 8 months

Systemic symptoms resolved with excision of tumor. Well at 9 months

Well at 3 months

Rapid resolution of constitutional symptoms after tumor excision. Well at 14 months

Well 5 years after surgery and adjuvant radiotherapy

Total excision; no follow-up information

Tumor debulking and evacuation of hematoma. Over the following years, patient had multiple intracranial recurrences, necessitating 10 operations. Died of progressive hydrocephalus from repeated hemorrhage at 49 months
EWS/ATF1

EWS rearranged

EWS/CREB1

FUS rearranged

NA

NA

FUS not rearranged; EWS FISH study unsatisfactory EWS/ATF1

EWS rearranged 
Table 2 Continued

\begin{tabular}{|c|c|c|c|c|c|}
\hline Source & $\begin{array}{l}\text { Sex/age } \\
\text { (years) }\end{array}$ & $\begin{array}{l}\text { Tumor location } \\
\text { and maximum } \\
\text { dimension }\end{array}$ & Presentation & Outcome & $\begin{array}{l}\text { Molecular } \\
\text { genetics }\end{array}$ \\
\hline Spencer et al ${ }^{9 a}$ & $\mathrm{~F} / 7$ & Bone (right mandible) & $\begin{array}{l}\text { One patient had } \\
\text { lymphadenopathy, fever, } \\
\text { nausea and vomiting and } \\
\text { weight loss }\end{array}$ & NA & NA \\
\hline Spencer et $a l^{9 a}$ & $\mathrm{M} / 8$ & $\begin{array}{l}\text { Bone (right proximal } \\
\text { humerus) }\end{array}$ & & $\begin{array}{l}\text { Treated by curettage. } \\
\text { Recurrence at } 3 \text { and } 9 \\
\text { months, necessitating } \\
\text { proximal humeral } \\
\text { resection }\end{array}$ & NA \\
\hline Spencer et al ${ }^{9 \mathrm{a}}$ & $\mathrm{M} / 47$ & $\begin{array}{l}\text { Bone (right proximal } \\
\text { ulnar shaft) }\end{array}$ & & $\begin{array}{l}\text { Treated by curettage. } \\
\text { Recurrence at } 7 \text { years }\end{array}$ & NA \\
\hline Somers et $\mathrm{al}^{7}$ & $\mathrm{~F} / 7$ & $\begin{array}{l}\text { Bone (left proximal } \\
\text { humeral diaphysis, } \\
\text { with significant } \\
\text { extraosseous } \\
\text { component), } 3.4 \mathrm{~cm}\end{array}$ & $\begin{array}{l}\text { Night fever, weight loss, } \\
\text { fatigue and anorexia. Recent } \\
\text { pain and swelling of the left } \\
\text { upper arm }\end{array}$ & $\begin{array}{l}\text { Chemotherapy (with } \\
\text { shrinkage of tumor), } \\
\text { followed by resection. } \\
\text { Well at } 7 \text { months after } \\
\text { initial biopsy }\end{array}$ & EWS/ATF1 \\
\hline Mangham et $a l^{6}$ & $\mathrm{M} / 11$ & $\begin{array}{l}\text { Bone (right proximal } \\
\text { humerus), } 5 \mathrm{~cm}\end{array}$ & $\begin{array}{l}\text { Two years' history of nausea, } \\
\text { vomiting, fever, weight loss } \\
\text { and growth retardation. A } \\
\text { right humeral expansile lytic } \\
\text { lesion detected on X-ray } \\
\text { taken after a blow to the right } \\
\text { upper arm }\end{array}$ & $\begin{array}{l}\text { Resection of proximal } \\
\text { humerus. Constitutional } \\
\text { symptoms resolved after } \\
\text { surgery. Well at } 16 \text { months }\end{array}$ & EWS/ATF1 \\
\hline Petrey et $a 1^{13}$ & $\mathrm{M} / 5$ & $\begin{array}{l}\text { Bone (left posterior } \\
\text { ischium, with a } \\
\text { significant } \\
\text { extraosseous } \\
\text { component) }\end{array}$ & $\begin{array}{l}\text { Left hip pain for } 1 \text { year, and } \\
\text { impaired ability of bearing } \\
\text { weight }\end{array}$ & $\begin{array}{l}\text { Treated by curettage. } \\
\text { Local recurrence at } 1 \text { year, } \\
\text { presenting with hip pain } \\
\text { and difficulties in } \\
\text { ambulation }\end{array}$ & EWS rearranged \\
\hline
\end{tabular}

${ }^{\mathrm{a}}$ Reported in the abstract form, and thus some details are not available.

striking feature was the presence of a peritumoral circumferential or incomplete band of lymphoid tissue, except case 5, which was incompletely removed in piecemeal (Figure 1). The lymphoid band comprised reactive lymphoid follicles separated by abundant small lymphocytes and plasma cells. The central portion of the tumor featured multiple discrete or coalescent pale-staining nodules that sometimes exhibited a plexiform or serpentine pattern, separated by a sclerotic stroma richly infiltrated by plasma cells (Figure 2). Sclerosis was particularly prominent in three cases (cases 6, 7 and 8) (Figure 1a).

Tumor cells were predominantly short spindly (three cases), predominantly oval (two cases) or mixed spindly and oval (three cases). The cells had oval or elongated nuclei, typically with fine chromatin. Nuclear grooving was prominent in two cases. Scattered cells with large hyperchromatic nuclei were commonly present, whereas diffuse moderate nuclear atypia was present in two cases (cases 5 and 6) (Figure 3). In case 6, the presence of many cells with bizarre and irregularly folded nuclei, coupled with growth in the form of islands separated by a desmoplastic-like stroma, resulted in an appearance highly reminiscent of poorly differentiated carcinoma (Figures 2c and 3d). However, mitotic figures were rare.
Tumor cells had indistinct cell borders and a moderate amount of eosinophilic cytoplasm. They formed sheets and nodular aggregates, with a whorled pattern being present at least focally (Figure 4). A storiform pattern was observed in three cases (cases 4, 5 and 7) (Figure 4b). Many cells showed clear cytoplasm in two cases (cases 3 and 8) (Figure 3c), and some cells showed eccentrically placed nuclei and abundant eosinophilic cytoplasm, resembling rhabdomyoblasts, in one case (case 5) (Figure 5a). Groups of cells with scanty cytoplasm (small cells), resembling Ewing's sarcoma, were present in two cases (cases 2 and 3) (Figure 5b). Deposition of myxoid material, edema fluid and/or proteinaceous fluid was present in all cases, at least as a focal phenomenon, and myxoid stroma was prominent in three cases (cases 4, 6 and 7). A resulting reticulated, microcystic or macrocystic growth pattern was observed in all except two cases (cases 3 and 5) (Figure 6). In two cases (cases 6 and 7), a pulmonary edema-like pattern was present in some foci (Figure 6c). In case 7, growth of tumor cells in cords within a myxoid stroma was present in areas (Figure 6d). In case 2, the presence of irregular clefts resulted in a hemangioendothelioma-like appearance focally (Figure 6e). In five cases, there were foci of hemorrhage, sometimes accompanied by formation of blood lakes 
a

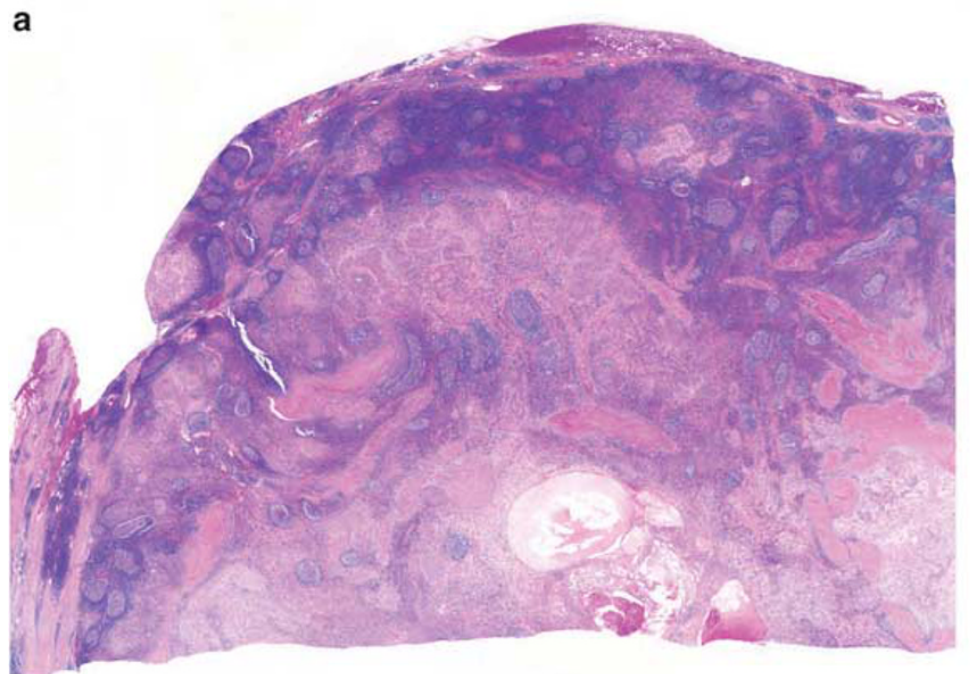

b

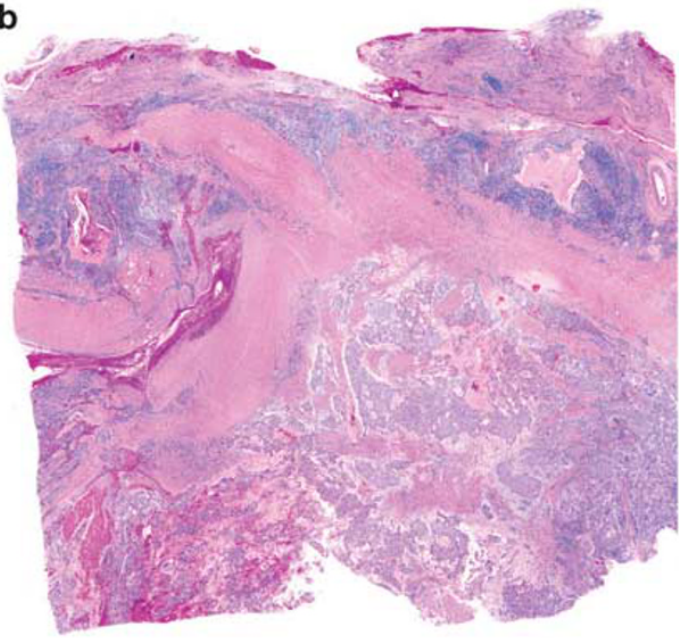

Figure 1 Scanning magnification view of tumors. (a) Retroperitoneal tumor of case 7, showing a prominent rim of lymphoid tissue rich in lymphoid follicles in the periphery. (b) Ovarian tumor of case 6, showing a fibrous pseudocapsule with lymphoid component on top. Anastomosing islands of tumor are seen in the lower field.
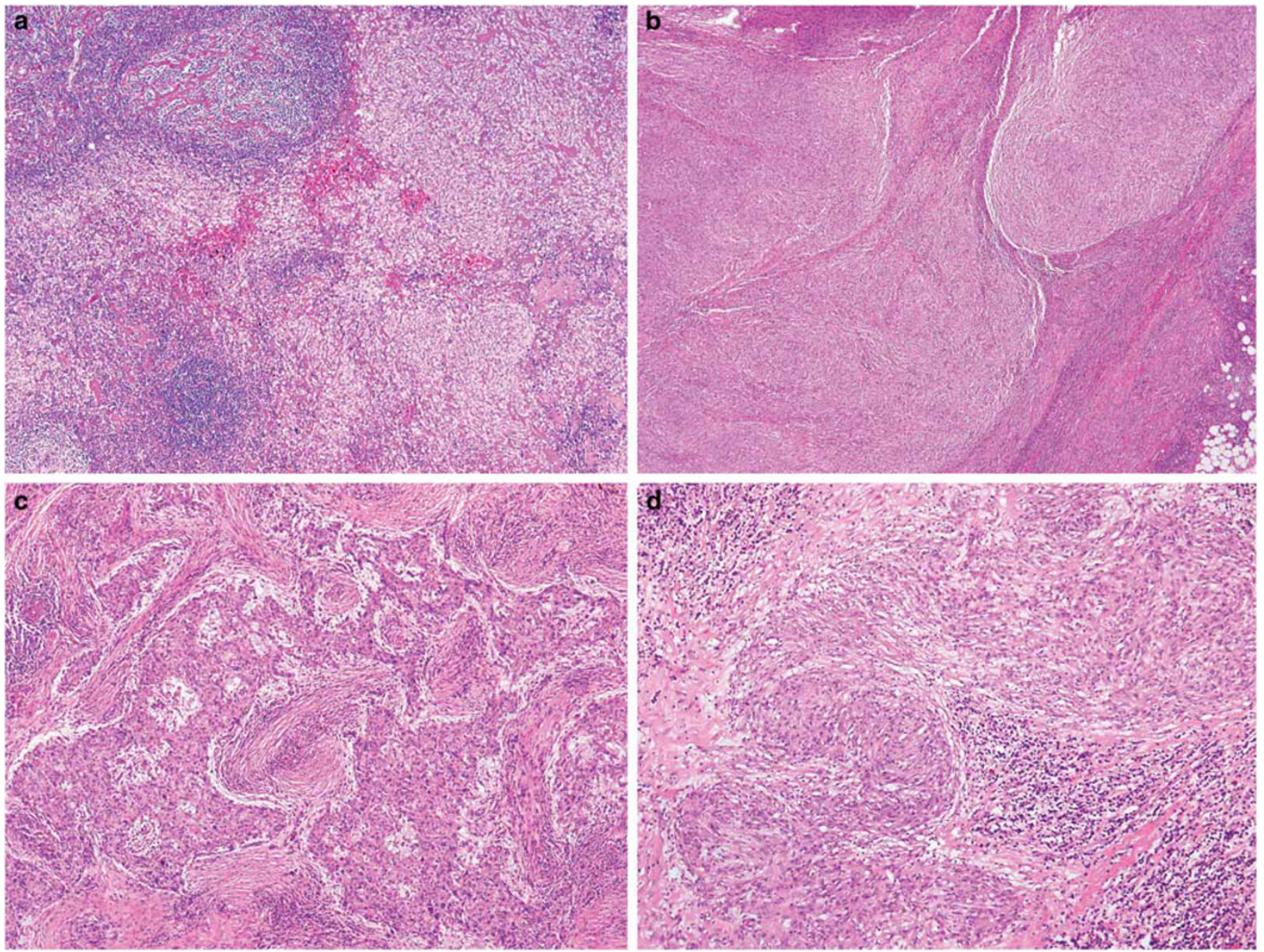

Figure 2 Architectural features. (a) Mediastinal tumor (case 8) comprising coalescent pale-staining nodules with interspersed lymphoid follicles and plasma cells. (b) Vulval tumor (case 4) showing closely packed, large, light-staining tumor nodules. (c) Ovarian tumor (case 6) with anastomosing plexiform islands of tumor separated by a sclerotic stroma infiltrated by chronic inflammatory cells. (d) Retroperitoneal tumor (case 7) with some tumor nodules assuming a serpentine configuration. The intervening stroma is infiltrated by chronic inflammatory cells. 

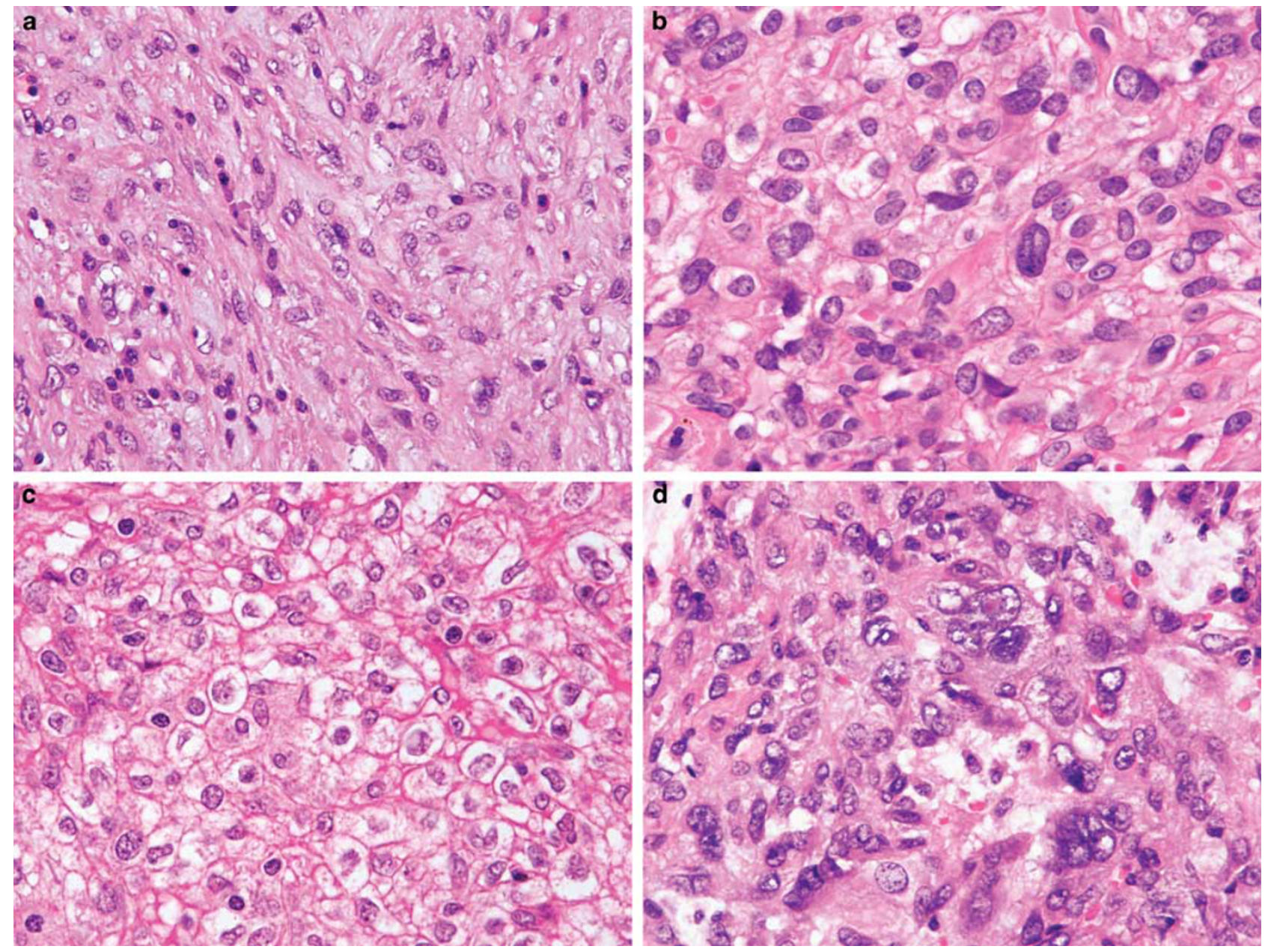

Figure 3 Cytological features. (a) Spindly tumor cells with uniform pale-staining nuclei. There are admixed plasma cells (case 4). (b) Oval tumor cells with fine nuclear chromatin. There are occasional cells with larger and more hyperchromatic nuclei (case 2). (c) Oval tumor cells with a clear cytoplasm (case 3). (d) The tumor cell nuclei are bizarre and pleomorphic. Coupled with the worrisome growth pattern in the form of anastomosing islands (see Figure 2c), the tumor may be mistaken for a poorly differentiated carcinoma (case 6).

and often accompanied by hemosiderin deposition (Figure 6f).

\section{Immunohistochemical Findings}

On immunostaining, cytokeratin was negative except in two cases, which featured small numbers of isolated positive tumor cells with dendritic cell processes (Table 1). Epithelial membrane antigen, CD68 and CD99 were expressed in all tested cases $(100 \%)$, desmin in five of eight cases $(62.5 \%)$ and smooth muscle actin in three of seven cases $(42.9 \%)$ (Figure 7). Focal CD21 expression was present in one case (Figure $7 \mathrm{~d}$ ). The Ki67 proliferative index was low, from 2 to $4 \%$.

\section{Molecular Studies}

On FISH analysis of seven cases, tumor cells showed break-apart signals of the EWS gene in six cases and of the FUS gene in one case (Table 1; Figure 7e). Break-apart signals were not detected in admixed plasma cells. RT-PCR analysis of five of the EWS-rearranged cases showed EWS-CREB1 gene fusion in three cases and EWS-ATF1 fusion in two cases.

\section{Discussion}

The eight tumors included in this series, all occurring in sites outside somatic soft tissues, exhibit morphological, immunophenotypic and molecular features characteristic of angiomatoid fibrous histiocytoma. This series also documents previously unrecognized sites of involvement by angiomatoid fibrous histiocytoma, including the vulva, ovary and retroperitoneum. Although the vulva may arguably be considered to represent somatic soft tissue, it can also be considered a distinct anatomical structure because of its origin 

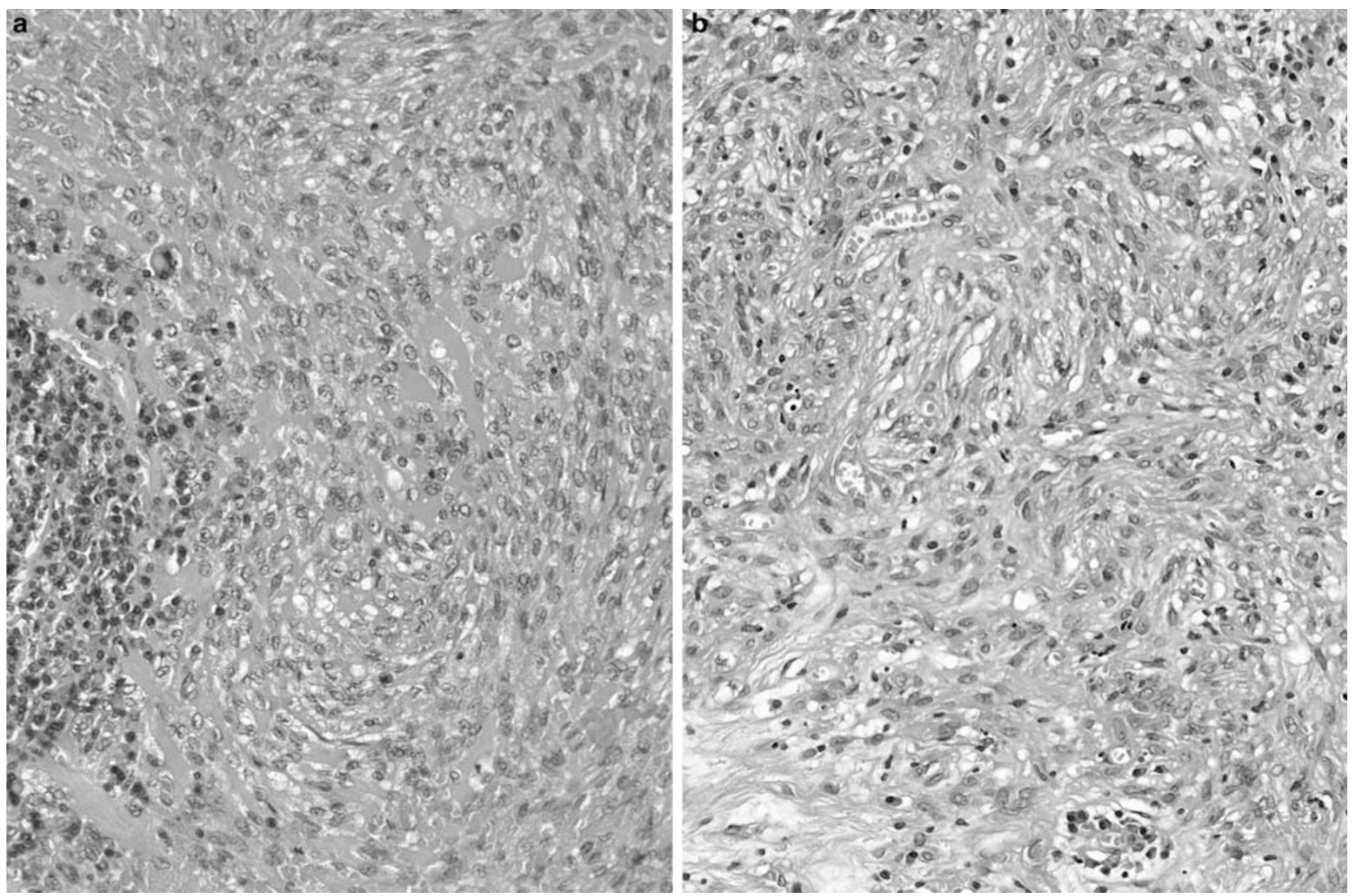

Figure 4 Cellular growth pattern. (a) Spindly cells forming circular whorls (case 8). (b) Storiform pattern (case 7).
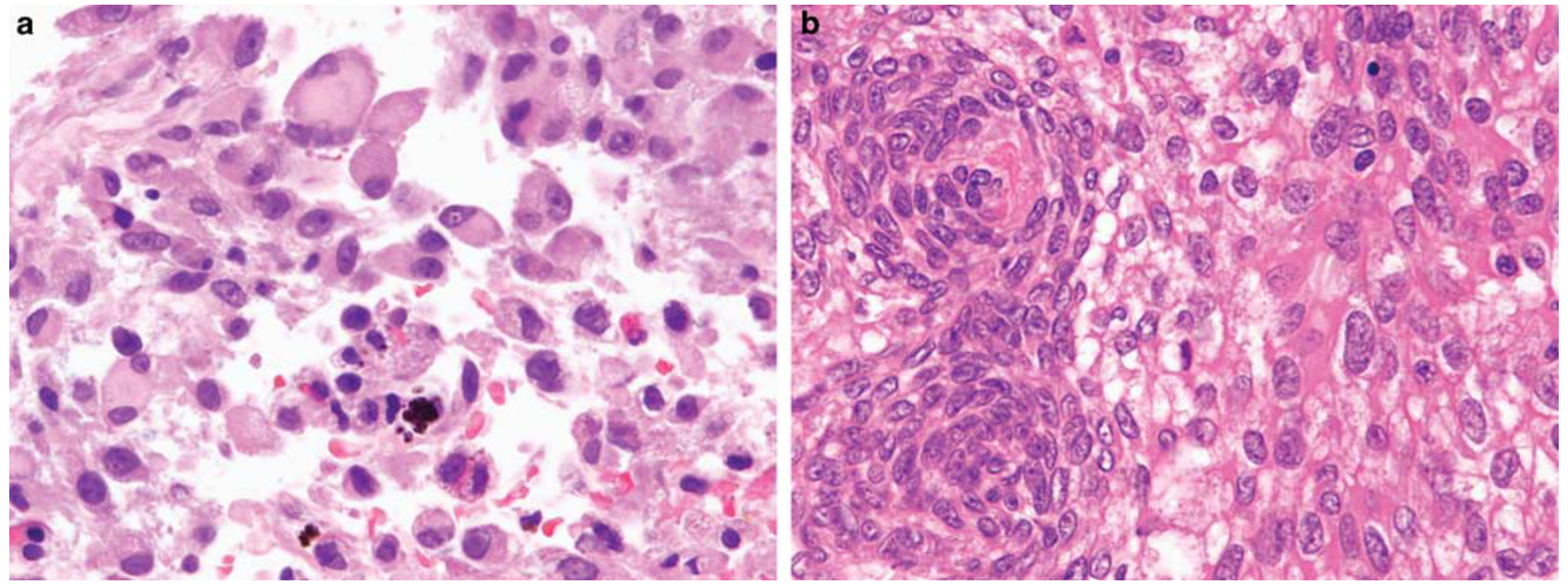

Figure 5 Unusual cytological features. (a) Focally, tumor cells have eccentrically placed nuclei and abundant eosinophilic cytoplasm, reminiscent of rhabdomyoblasts (case 5). (b) Focal presence of small cells-tumor cells in the left field show a high nuclear-cytoplasmic ratio and slightly smaller nuclei compared with the rest of the tumor (case 3).

from the genital tubercle and folds, presence of erectile tissue in the labia minora, presence of specialized hormone-responsive stromal cells and being the host to some fairly site-specific mesenchymal tumors (such as angiomyofibroblastoma and aggressive angiomyxoma). ${ }^{17}$
The best histological clue to the diagnosis of angiomatoid fibrous histiocytoma is the peritumoral cuff of lymphoplasmacytic infiltrate, ${ }^{2,3,18}$ a feature rarely seen in other tumors except gastrointestinal schwannoma. ${ }^{19}$ Other distinctive morphological features are multinodular tumor growth, dendritic 

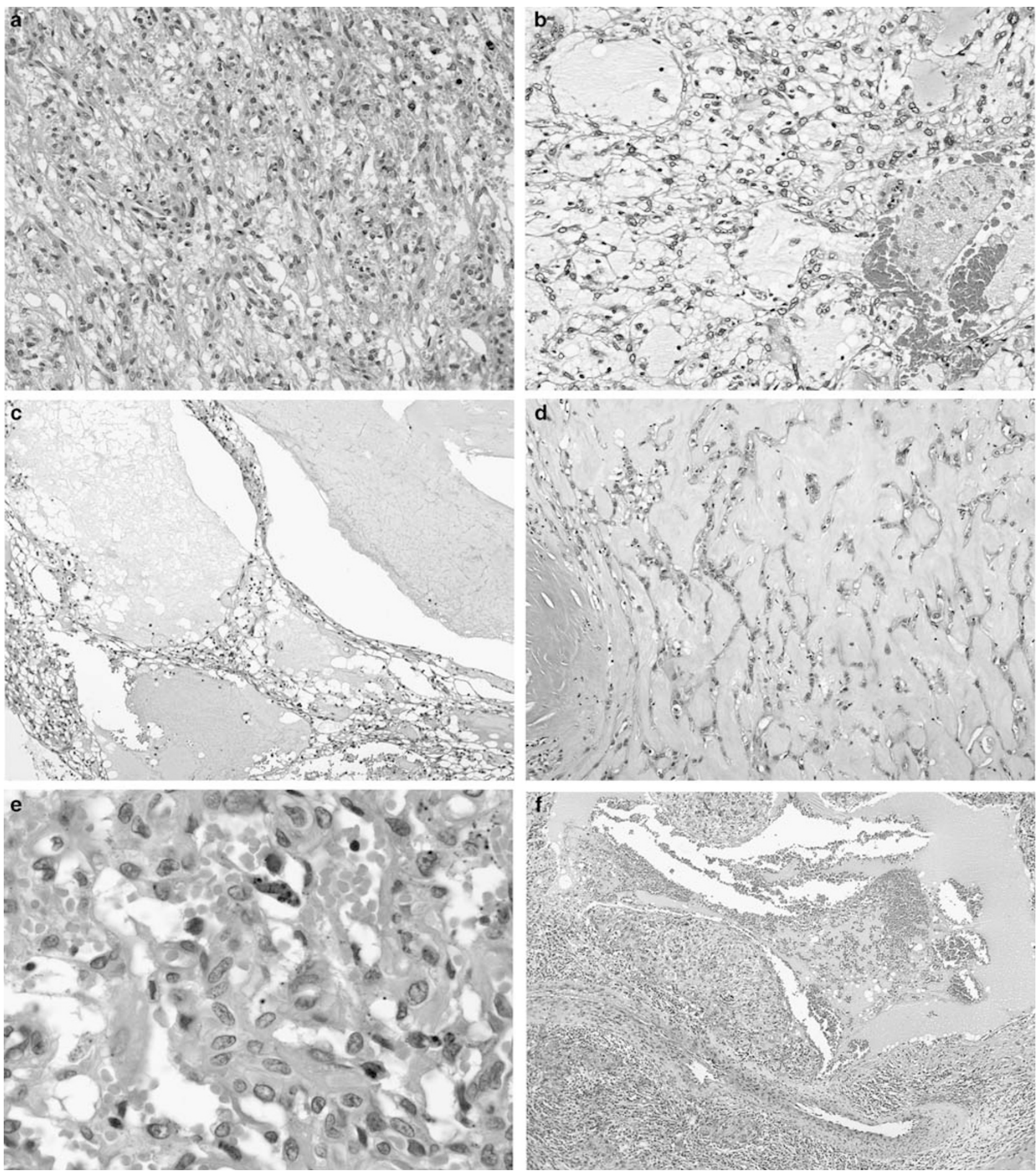

Figure 6 Stromal changes. (a) Spindly tumor cells are loosely disposed in an edematous-myxoid stroma. Interstitial hemorrhage is also evident (case 2). (b) Microcystic appearance due to interstitial accumulation of mucinous material (case 6). (c) Formation of macrocystic spaces filled with proteinaceous fluid creates a pulmonary edema-like pattern (case 7). (d) Cords of tumor cells lie in a myxoid stroma, mimicking the architectural features of myxoid chondrosarcoma (case 7). (e) Irregular narrow spaces, sometimes containing red cells, are present among tumor cells, resulting in a hemangioendothelioma-like appearance (case 2). (f) A blood-filled cavity is present (case 6).

cell tumor-like morphology (tumor cells with eosinophilic cytoplasm and indistinct cell borders) and abundant admixed plasma cells. ${ }^{1-3,18}$ However, some cases in this series exhibit previously unreported or unusual morphological features focally, increasing the difficulties in the diagnosis of angiomatoid fibrous histiocytoma in extrasomatic locations. These include clear cells, rhabdomyoblast-like cells, 

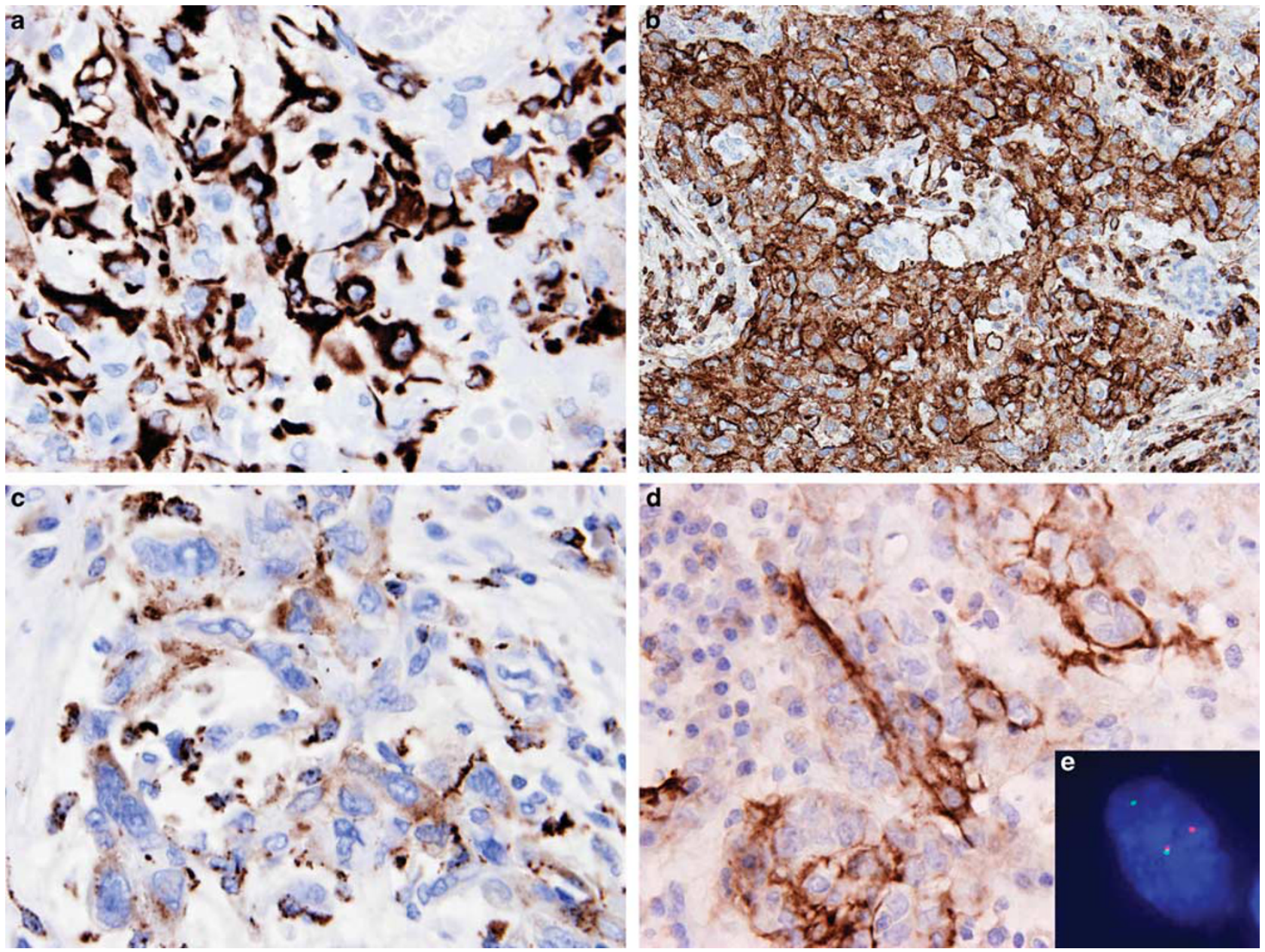

Figure 7 (a) Immunostaining shows desmin-positive tumor cells with dendritic cell processes (case 6). (b) Immunostaining for epithelial membrane antigen is positive. Admixed plasma cells are also highlighted (case 6). (c) Some tumor cells show cytoplasmic immunostaining for CD68 (case 6). (d) Rare tumor cells show a dendritic pattern of CD21 immunostaining (case 7). (e) Fluorescence in situ hybridization using break-apart probes for the EWS gene shows one red, one green and one combined signal in the nucleus. The presence of separate red and green signals indicates the presence of translocation involving the EWS gene.

pulmonary edema-like pattern and tumor cells forming cords in a myxoid stroma.

As angiomatoid fibrous histiocytoma lacks a specific immunophenotype, immunohistochemical studies are supportive rather than diagnostic. Positivity rates for the various immunohistochemical markers in the cases of this series are broadly similar to those reported in large series. ${ }^{3,18}$ Although the presence of clusters of desmin-positive cells with a dendritic morphology is characteristic, this is found in only half of the cases and can be seen in other tumor types such as tenosynovial giant cell tumor. ${ }^{18,20,21}$ There is variable immunoreactivity for the epithelial membrane antigen, CD68, smoothmuscle actin, calponin and CD99. ${ }^{3,10,18,22}$ One case in this series shows an unexpected focal staining for CD21, which taken together with the dendritic cell tumor-like morphology and prominent lymphoid stroma, may lead to an erroneous diagnosis of follicular dendritic cell sarcoma.
On the other hand, molecular studies are most helpful for confirming a diagnosis of angiomatoid fibrous histiocytoma, especially as these ancillary tools are applicable to routine paraffin-embedded tissues. ${ }^{4,23}$ Distinctive chromosomal translocations are found in practically all cases of angiomatoid fibrous histiocytoma, with EWS/CREB1 fusion being the most common ( $>75 \%$ of cases), others being EWS/ATF1 and FUS/ATF1 (Table 3). ${ }^{4,24-31}$ The only other types of neoplasms known to show EWS/ATF1 or EWS/CREB1 gene fusion are clear cell sarcoma of soft tissues and osteoclast-rich tumor of the gastrointestinal tract with features resembling clear cell sarcoma of soft parts, and more recently hyalinizing clear cell carcinoma of the salivary gland (EWSATF1). ${ }^{15,32,33}$ However, these tumor types are morphologically very different. Molecular studies are most invaluable for supporting a diagnosis of angiomatoid fibrous histiocytoma occurring in unusual sites or showing unusual morphological features. 
Table 3 Comparison of reported cases of angiomatoid fibrous histiocytoma occurring outside somatic soft tissues with those involving somatic soft tissues

\begin{tabular}{|c|c|c|}
\hline & $\begin{array}{l}\text { Angiomatoid fibrous histiocytoma occurring } \\
\text { outside somatic soft tissues }\end{array}$ & $\begin{array}{l}\text { Conventional angiomatoid fibrous } \\
\text { histiocytoma of somatic soft tissues }\end{array}$ \\
\hline Age & $\begin{array}{l}\text { Median age } 35 \text { years, with only } 26 \% \text { under the } \\
\text { age of } 20 \text { years. The subgroup occurring in the } \\
\text { bone occurs predominantly in the first two } \\
\text { decades, with a median age of } 7.5 \text { years }\end{array}$ & $\begin{array}{l}\text { Reported median age ranges from } 12 \text { to } 18 \\
\text { years, with } 80 \% \text { under the age of } 20 \text { years }\end{array}$ \\
\hline Sex & $\begin{array}{l}\text { No significant sex predilection (male to female } \\
\text { 10:9). The subgroup occurring in the bone shows } \\
\text { male predilection (male-to-female ratio } 4: 2 \text { ) }\end{array}$ & $\begin{array}{l}\text { Slight female or male predominance, varying } \\
\text { with different reports }\end{array}$ \\
\hline $\begin{array}{l}\text { Systemic inflammatory } \\
\text { symptoms }\end{array}$ & $5 / 18(28 \%)$ & $10-15 \%$ \\
\hline Tumor size & Median size $2.9 \mathrm{~cm}$; mean size $3.3 \mathrm{~cm}$ & Median size reported to be $2-2.8 \mathrm{~cm}$ \\
\hline Clinical outcome & Recurrence rate $5 / 15(33 \%)$ & $\begin{array}{l}\text { On mean follow-up of } 63 \text { months, local } \\
\text { recurrence in } 11 \% \text {, local recurrence and } \\
\text { metastasis in } 1 \% \text {, local metastasis in } 3 \% \\
\text { and distant metastasis in } 1 \%\end{array}$ \\
\hline Histological findings & $\begin{array}{l}\text { Clear cells in } 25 \% \text { of cases. } \\
\text { Prominent myxoid change in } 38 \%\end{array}$ & $\begin{array}{l}\text { No clear cells. } \\
\text { Prominent myxoid change in } 9-13 \%\end{array}$ \\
\hline Molecular genetics & $\begin{array}{l}\text { EWS translocation in } 92 \%(11 / 12), \text { with } 38 \% \\
(3 / 8) \text { being EWS-CREB1 and } 63 \%(5 / 8) \\
\text { EWS-ATF1. } \\
\text { FUS translocation in } 1 / 12(8 \%)\end{array}$ & $\begin{array}{l}\text { EWS translocation in } 93 \% \text {, with } 81 \% \text { being } \\
\text { EWS-CREB1 and } 19 \% \text { EWS-ATF1. } \\
\text { FUS translocation in } 7 \%\end{array}$ \\
\hline
\end{tabular}

Comparison of angiomatoid fibrous histiocytomas occurring outside somatic soft tissues with their somatic soft tissue counterparts reveals a number of differences (summarized in Table 3), with the caveat that the number of cases in the former category is small. ${ }^{1,2,18,34}$ First, the median age is higher, by $\sim 20$ years. Second, although there is no significant sex predilection in either, the subgroup occurring in bone shows male predilection (male-to-female ratio: 4:2). Third, systemic inflammatory symptoms occur more frequently (30 vs 10-15\%). Fourth, the tumors tend to be slightly larger, by $\sim 0.5 \mathrm{~cm}$. Fifth, the local recurrence rate is higher despite a shorter follow-up duration ( $>33$ vs $<15 \%$ ). This may be related to the strategic location (such as the bone and brain), whereby complete excision is more difficult to achieve. Sixth, myxoid stromal change is more common (seen in all cases, and prominent in 38\% of cases), and clear cells can occur in some cases. Seventh, there are differences in the pattern of $E W S$ gene translocation-with EWS/ATF1 fusion being much more common (63 vs 19\%).

In conclusion, angiomatoid fibrous histiocytoma can occur in diverse anatomical locations, and additional new sites of involvement will almost certainly be recognized in future. We speculate that angiomatoid fibrous histiocytoma may be an underrecognized tumor outside somatic soft tissues, and bona fide cases have probably been subsumed among cases diagnosed as inflammatory myofibroblastic tumor, follicular dendritic cell sarcoma, poorly differentiated carcinoma or meningioma. Increased awareness of the morphological character- istics of angiomatoid fibrous histiocytoma (in particular, the peritumoral lymphoid cuff) and its potential occurrence in unusual sites will aid in its recognition.

\section{Disclosure/conflict of interest}

The authors declare no conflict of interest.

\section{References}

1 Enzinger FM. Angiomatoid malignant fibrous histiocytoma: a distinct fibrohistiocytic tumor of children and young adults simulating a vascular neoplasm. Cancer 1979;44:2147-2157.

2 Costa MJ, Weiss SW. Angiomatoid malignant fibrous histiocytoma. A follow-up study of 108 cases with evaluation of possible histologic predictors of outcome. Am J Surg Pathol 1990;14:1126-1132.

3 Fanburg-Smith JC. Angiomatoid fibrous histiocytoma. In: Fletcher CDM, Unni KK, Mertens F (eds). World Health Organization Classification of Tumours. Pathology and Genetics. Tumours of Soft Tissue and Bone. Lyon: IARC, 2002, pp 194-195.

4 Dunham C, Hussong J, Seiff $\mathrm{M}$, et al. Primary intracerebral angiomatoid fibrous histiocytoma: report of a case with a $\mathrm{t}(12 ; 22)(\mathrm{q} 13 ; \mathrm{q} 12)$ causing type 1 fusion of the EWS and ATF-1 genes. Am J Surg Pathol 2008;32:478-484.

5 Asakura S, Tezuka N, Inoue S, et al. Angiomatoid fibrous histiocytoma in mediastinum. Ann Thorac Surg 2001;72:283-285.

6 Mangham DC, Williams A, Lalam RK, et al. Angiomatoid fibrous histiocytoma of bone: a calcifying 
sclerosing variant mimicking osteosarcoma. Am J Surg Pathol 2010;34:279-285.

7 Somers GR, Viero S, Nathan PC, et al. Association of the $\mathrm{t}(12 ; 22)(\mathrm{q} 13 ; \mathrm{q} 12)$ EWS/ATF1 rearrangement with polyphenotypic round cell sarcoma of bone: a case report. Am J Surg Pathol 2005;29:1673-1679.

8 Ren L, Guo SP, Zhou XG, et al. Angiomatoid fibrous histiocytoma: first report of primary pulmonary origin. Am J Surg Pathol 2009;33:1570-1574.

9 Spencer ML, Ayala AG, Dorfman HD, et al. Angiomatoid fibrous histiocytoma of bone (Abstr). Lab Invest 2005;85(Suppl 1S):22A.

10 Tanas MR, Rubin BP, Montgomery EA, et al. Utility of FISH in the diagnosis of angiomatoid fibrous histiocytoma: a series of 18 cases. Mod Pathol 2010;23: 93-97.

11 Ochalski PG, Edinger JT, Horowitz MB, et al. Intracranial angiomatoid fibrous histiocytoma presenting as recurrent multifocal intraparenchymal hemorrhage. J Neurosurg 2010;112:978-982.

12 Davies KA, Cope AP, Schofield JB, et al. A rare mediastinal tumour presenting with systemic effects due to IL-6 and tumour necrosis factor (TNF) production. Clin Exp Immunol 1995;99:117-123.

13 Petrey WB, LeGallo RD, Fox MG, et al. Imaging characteristics of angiomatoid fibrous histiocytoma of bone. Skeletal Radiol 2011;40:233-237.

14 Antonescu CR, Tschernyavsky SJ, Woodruff JM, et al. Molecular diagnosis of clear cell sarcoma. J Mol Diagn 2002;4:44-52.

15 Wang WL, Mayordomo E, Zhang W, et al. Detection and characterization of EWSR1/ATF1 and EWSR1/ CREB1 chimeric transcripts in clear cell sarcoma (melanoma of soft parts). Mod Pathol 2009;22: 1201-1209.

16 Antonescu CR, Nafa K, Segal NH, et al. EWS-CREB1: a recurrent variant fusion in clear cell sarcoma-association with gastrointestinal location and absence of melanocytic differentiation. Clin Cancer Res 2006;12: 5356-5362.

17 Wilkinson EJ, Hardt NS. Vulva 3rd edn. Lippincott Williams \& Wilkins: Philadelphia, 2007, pp 983-987.

18 Fanburg-Smith JC, Miettinen M. Angiomatoid 'malignant' fibrous histiocytoma: a clinicopathologic study of 158 cases and further exploration of the myoid phenotype. Hum Pathol 1999;30:1336-1343.

19 Daimaru $\mathrm{Y}$, Kido $\mathrm{H}$, Hashimoto $\mathrm{H}$, et al. Benign schwannoma of the gastrointestinal tract: a clinicopathologic and immunohistochemical study. Hum Pathol 1988;19:257-264.

20 Fletcher CD. Angiomatoid 'malignant fibrous histiocytoma': an immunohistochemical study indicative of myoid differentiation. Hum Pathol 1991;22:563-568.

21 Somerhausen NS, Fletcher CD. Diffuse-type giant cell tumor: clinicopathologic and immunohistochemical analysis of 50 cases with extraarticular disease. Am J Surg Pathol 2000;24:479-492.

22 Hasegawa $\mathrm{T}$, Seki K, Ono K, et al. Angiomatoid (malignant) fibrous histiocytoma: a peculiar lowgrade tumor showing immunophenotypic heterogeneity and ultrastructural variations. Pathol Int 2000; 50:731-738.

23 Weinreb I, Rubin BP, Goldblum JR. Pleomorphic angiomatoid fibrous histiocytoma: a case confirmed by fluorescence in situ hybridization analysis for EWSR1 rearrangement. J Cutan Pathol 2008;35: 855-860.

24 Thway K. Angiomatoid fibrous histiocytoma: a review with recent genetic findings. Arch Pathol Lab Med 2008;132:273-277.

25 Shao L, Singh V, Cooley L. Angiomatoid fibrous histiocytoma with $\mathrm{t}(2 ; 22)(\mathrm{q} 33 ; \mathrm{q} 12.2)$ and EWSR1 gene rearrangement. Pediatr Dev Pathol 2009;12:143-146.

26 Rossi S, Szuhai K, Ijszenga M, et al. EWSR1-CREB1 and EWSR1-ATF1 fusion genes in angiomatoid fibrous histiocytoma. Clin Cancer Res 2007;13:7322-7328.

27 Antonescu CR, Dal Cin P, Nafa K, et al. EWSR1-CREB1 is the predominant gene fusion in angiomatoid fibrous histiocytoma. Genes Chromosomes Cancer 2007;46: 1051-1060.

28 Hallor KH, Micci F, Meis-Kindblom JM, et al. Fusion genes in angiomatoid fibrous histiocytoma. Cancer Lett 2007;251:158-163.

29 Hallor KH, Mertens F, Jin Y, et al. Fusion of the EWSR1 and ATF1 genes without expression of the MITF-M transcript in angiomatoid fibrous histiocytoma. Genes Chromosomes Cancer 2005;44:97-102.

30 Raddaoui E, Donner LR, Panagopoulos I. Fusion of the FUS and ATF1 genes in a large, deep-seated angiomatoid fibrous histiocytoma. Diagn Mol Pathol 2002;11: 157-162.

31 Waters BL, Panagopoulos I, Allen EF. Genetic characterization of angiomatoid fibrous histiocytoma identifies fusion of the FUS and ATF-1 genes induced by a chromosomal translocation involving bands 12q13 and 16p11. Cancer Genet Cytogenet 2000;121: 109-116.

32 Kosemehmetoglu K, Folpe AL. Clear cell sarcoma of tendons and aponeuroses, and osteoclast-rich tumour of the gastrointestinal tract with features resembling clear cell sarcoma of soft parts: a review and update. J Clin Pathol 2010;63:416-423.

33 Antonescu CR, Katabi N, Zhang L, et al. Rearrangement of the EWSR1 gene is a consistent feature in hyalinizing clear cell carcinoma of salivary gland. (Abstr). Mod Pathol 2011;26(Suppl 1):273A.

34 Pettinato G, Manivel JC, De Rosa G, et al. Angiomatoid malignant fibrous histiocytoma: cytologic, immunohistochemical, ultrastructural, and flow cytometric study of 20 cases. Mod Pathol 1990;3:479-487. 